\title{
Papillary, Follicular, Hurthle Cell, Poorly Differentiated, and Anaplastic Thyroid Carcinoma pT1a TNM Finding v8
}

National Cancer Institute

\section{Source}

National Cancer Institute. Papillary, Follicular, Hurthle Cell, Poorly Differentiated, and Anaplastic Thyroid Carcinoma pT 1a TNM Finding v8. NCI Thesaurus. Code C140916.

Tumor measuring $1 \mathrm{~cm}$ or less in greatest dimension limited to the thyroid. (from AJCC 8th Ed.) 